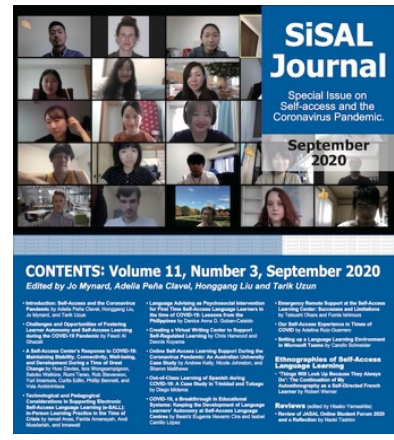

ISSN 2185-3762

\title{
Studies in Self-Access Learning Journal
}

http://sisaljournal.org

\section{Introduction: Self-Access and the Coronavirus Pandemic}

Adelia Peña Clavel, National Autonomous University of Mexico, Mexico City, Mexico

Jo Mynard, Kanda University of International Studies, Chiba, Japan

Honggang Liu, Northeast Normal University, Changchun, China

Tarik Uzun, Ankara Yıldırım Beyazıt University, Ankara, Turkey

Corresponding author: editor@sisaljournal.org

Publication date: September, 2020.

\section{To cite this article}

Peña Clavel, M. A., Mynard, J., Liu, H., \& Uzun, T. (2020). Introduction: Self-access and the coronavirus pandemic. Studies in Self-Access Learning Journal, 11(3), 108-113.

https://doi.org/10.37237/110301

\section{To link to this article}

http://sisaljournal.org/archives/sep20/introduction

This article may be used for research, teaching and private study purposes. Please contact the authors for permission to re-print elsewhere.

Scroll down for article. 
Volume 11, Number 3, September 2020: Special Issue on Self-access and the Coronavirus Pandemic. Edited by Jo Mynard, Adelia Peña Clavel, Honggang Liu and Tarik Uzun

- Introduction: Self-Access and the Coronavirus Pandemic by Adelia Peña Clavel, Honggang Liu, Jo Mynard, and Tarik Uzun (108-113)

- Challenges and Opportunities of Fostering Learner Autonomy and SelfAccess Learning during the COVID-19 Pandemic by Fawzi Al Ghazali (114-127)

- Technological and Pedagogical Considerations in Supporting Electronic SelfAccess Language Learning (e-SALL): In-Person Learning Practice in the Time of Crisis by Ismail Anas, Farida Amansyah, Andi Musdariah, and Irmawati (128-134)

- A Self-Access Center's Response to COVID-19: Maintaining Stability, Connectivity, Well-being, and Development During a Time of Great Change by Huw Davies, Isra Wongsarnpigoon, Satoko Watkins, Rumi Terao, Rob Stevenson, Yuri Imamura, Curtis Edlin, Phillip Bennett, and Dominique Vola Ambinintsoa (135-147)

- Language Advising as Psychosocial Intervention for First Time Self-Access Language Learners in the time of COVID-19: Lessons from the Philippines by Danica Anna D. Guban-Caisido (148-163)

- Creating a Virtual Writing Center to Support Self-Regulated Learning by Chris Harwood and Dennis Koyama (164-186)

- Online Self-Access Learning Support During the Coronavirus Pandemic: An Australian University Case Study by Andrew Kelly, Nicole Johnston, and Sharon Matthews (187-198)

- Out-of-Class Learning of Spanish During COVID-19: A Case Study in Trinidad and Tobago by Diego Mideros (199-219)

- COVID-19, a Breakthrough in Educational Systems: Keeping the Development of Language Learners' Autonomy at Self-Access Language Centres by Beatriz Eugenia Navarro Cira and Isabel Carrillo López (220-234)

- Emergency Remote Support at the Self-Access Learning Center: Successes and Limitations by Tetsushi Ohara and Fumie Ishimura (235-249)

- Our Self-Access Experience in Times of COVID by Adelina Ruiz-Guerrero (250-262)

- Setting Up a Language Learning Environment in Microsoft Teams by Carolin Schneider (263-270)

Ethnographies of Self-Access Language Learning

- 'Things Will Look Up Because They Always Do': The Continuation of My Autoethnography as a Self-Directed French Learner by Robert Werner (271-293)

Reviews (edited by Hisako Yamashita)

- Review of JASAL Online Student Forum 2020 and a Reflection by Naoki Tashiro (294-297)

Index 
SiSAL Journal Vol. 11, No. 3, September 2020, 108-113.

\section{Introduction: Self-Access and the Coronavirus Pandemic}

Adelia Peña Clavel, National Autonomous University of Mexico, Mexico City Mexico

Jo Mynard, Kanda University of International Studies, Chiba, Japan

Honggang Liu, Northeast Normal University, Changchun, China

Tarik Uzun, Ankara Yıldırım Beyazıt University, Ankara, Turkey

Welcome to the special issue on self-access and the coronavirus pandemic. When we first had the idea to compile this special issue back in March 2020, we did so, not knowing how the year would pan out. Some parts of the world had already been severely impacted by the coronavirus, but others hardly touched. Many students and academics in various countries were waiting for leaders in their institutions to make decisions about how classes and academic support would be offered. We assumed that we would not be able to run our self-access centres as usual and were beginning to think of ways we could adapt our services. Being in unchartered waters, we were genuinely looking for ideas about how to proceed and how to keep supporting students in these unprecedented times. Self-access practitioners tend to be trailblazers by nature (Mynard, 2019), but this was indeed a challenge for all of us. However, as you will see in the various contributions in this special issue, this turbulent time gave us a chance to innovate and overcome many of the challenges. The call for papers resulted in contributions from around the world and one of the most international issues of SiSAL Journal to date. We are grateful to the authors and reviewers for their contributions to this special issue, and also to the two other members of our editorial team: Metin Esen from Ankara Yıldırım Beyazıt University, Turkey and Gao Lixiang, a PhD candidate in language education from Northeast Normal University, China. Acknowledgements also go to Robert Werner, the Associate Editor of SiSAL Journal, for his advice and careful copyediting.

There are 11 papers in this issue related to supporting self-access learning during the coronavirus pandemic. Several themes emerge from these papers including online advising, online learning communities, technological innovation, and online resources - all with a focus on promoting autonomous language learning. We are also pleased to include one article in our 'Ethnographies of self-access' column and one review.

\section{Self-Access and the Coronavirus Pandemic}

This is a particularly international issue of SiSAL Journal with papers from Australia, Indonesia, Japan, Mexico, the Philippines, Trinidad and Tobago, the United Arab Emirates, and the United Kingdom. As all of the papers are multi-faceted, it was difficult for the editors to group them 
SiSAL Journal Vol. 11, No. 3, September 2020, 108-113.

thematically in this issue, so we have instead presented them in alphabetical order by the first author's surname. Please refer to the index at the end of the issue for a summary table.

In the first paper, Fawzi Al Ghazali from the University of Sharjah in the UAE begins with a summary of the impact that the 2020 coronavirus pandemic has had on society. The author then gives an overview of different kinds of self-access and virtual learning which serves as a useful theoretical backdrop for the case studies that follow in this issue. The paper ends with some recommendations for ways that teachers and education authorities need to respond in such times in order to support learners and promote learner autonomy.

In the second paper, Ismail Anas, Farida Amansyah, Andi Musdariah, and Irmawati from Politeknik Negeri Ujung Pandang in Indonesia offer some perspectives on facilitating selfaccess learning using web-based technologies. The authors explore how a Learning Management System (LMS) can be integrated with other internet-based materials and resources in order to sustain learning. The authors also discuss how an online community of practice (OCoP) can play a role in self-access language learning.

The third paper is a summary of one institution's response provided by Huw Davies, Isra Wongsarnpigoon, Satoko Watkins, Dominique Vola Ambinintsoa, Rumi Terao, Rob Stevenson, Yuri Imamura, Curtis Edlin, and Phillip A. Bennett who are based at Kanda University of International Studies in Japan. The authors include academic and administrative staff who give a big-picture overview of the structure and response of their center. The authors share their reflections about moving online and experiencing the learners' communities, the self-access modules, and learning advising in an online model. They also consider, as do some other authors in this volume, the well-being of both students and advisors. The suggestions at the end could be steppingstones for other SALCs or social spaces.

In the fourth paper, Danica Anna D. Guban-Caisido from the University of the Philippines Diliman in the Philippines presents an interesting study about the implementation of an emergent program based on Advising in Language Learning (ALL) methodology (Carson \& Mynard, 2012). The participants were a small group of students in the Philippines who were attempting to cope with online learning once the school doors closed due to the COVID-19 outbreak. The aim of the ALL was to help students with their learning progress and be a channel for psychosocial support during the times of confinement. This study allows us to see how ALL methodology was a valuable aid to students and showed its future potential in other environments.

In the fifth paper, Chris Harwood and Dennis Koyama based at Sophia University in Tokyo, Japan report the project of setting up a synchronous online writing centre with the affordances of video conferencing technology during the COVID-19 pandemic and demonstrate 
SiSAL Journal Vol. 11, No. 3, September 2020, 108-113.

how this centre supports students' autonomous online writing. It was found that the online writing centre supported the learners' self-directed learning cycles from goal setting, goal refining through tutorials, to self-reflection. Meaningful interactions are also promoted which enhance the cooperation, engagement, and autonomous learning.

Andrew Kelly, Nicole Johnston, and Sharon Matthews from Edith Cowan University in Australia share three key self-access academic support services, namely, online self-access learning support, individual videoconference appointments with learning advisers and librarians, and peerto-peer virtual guides to online learning. The paper focuses on how these services support students' online learning in response to the coronavirus pandemic. The authors also suggest practical implications for maximising the positive effects of these services and summarise the progress in these self-access initiatives for future development.

Next, Diego Mideros from The University of the West Indies (St. Augustine Campus) in Trinidad and Tobago presents a qualitative study that gives voice to 15 students who experience learning Spanish independently. Mideros created an environment that allowed his students to have free access to materials, and he monitored their progress via WhatsApp. The aim was to promote autonomy beyond the classroom particularly in this situation of remote teaching. His findings are unexpected at some points, but also they show that students can be engaged in their own learning. However, there is also a need for encouraging learning outside the classroom.

The next paper was written by Beatriz Eugenia Navarro Cira from the Universidad Michoacana de San Nicolas de Hidalgo and Isabel Carrillo López from the Universidad Autonoma de Queretaro both in Mexico. The authors present two operational models which function as useful guidelines in the provision of advising services and workshops at a self-access center in times of global pandemic. In the paper, the authors propose working schemes for advising and the design of online activities via step-by-step procedures. It is also underlined in the paper that such procedures are applicable to other self-access centers in different contexts as well.

Tetsushi Ohara and Fumie Ishimura from Ritsumeikan Asia Pacific University (APU) in Japan present their approach in supporting learners during the days of the coronavirus pandemic. The authors first describe Emergency Remote Support (ERS) which characterizes their approach to SALC activities and introduce their research with peer advisors (PA) who work for the center. The authors discuss survey and interview results by drawing on both the successful points and limitations of ERS.

After that, Adelina Ruiz-Guerrero from the Jesuit University of Guadalajara (ITESO) in Mexico introduces how the Self-Access Center based at the university responded to the coronavirus pandemic and adapted its ongoing activities to the ongoing emergency situation. The author first 
SiSAL Journal Vol. 11, No. 3, September 2020, 108-113.

presents the instant changes that were implemented once the crisis broke out, then describes how advising and tutoring sessions along with conversation club activities were carried out online via Zoom and other electronic tools.

In the final paper on the theme of the coronavirus pandemic, Carolin Schneider from the University of Leeds in the UK offers a summary of the modifications of the Language Zone in terms of the provision and team members' roles in the Microsoft Teams learning environment in response to the pandemic. The author also gives an overview of a platform developed by the Language Zone to support the 2020 summer pre-sessional programmes to be delivered completely online. Finally, Schneider confirms the progress of the online learning project and anticipates future development of the Language Zone team self-access service in the post-pandemic future.

\section{Regular Column: Ethnographies of Self-Access Language Learning}

This section contains the second instalment of an autoethnography provided by Robert $\mathbf{J}$. Werner from Ryutsu Keizai University in Japan. In his paper, the author continues where he left off in the previous issue (Werner, 2020) with the description of his experience with his self-directed learning of French.

\section{Reviews (edited by Hisako Yamashita)}

Naoki Tashiro, a student at Gifu Shotoku Gakuen University in Japan, provides a review and some brief reflections on the first online student forum of the Japan Association for Self-Access learning (JASAL).

\section{Call for Papers}

We welcome ethnographies, autoethnographies, collaborative ethnographies, or duoethnographies related to self-access learning from authors to future issues of the journal for the 'Ethnographies of Self-Access Language Learning' column. Please refer to Mynard (2020) for examples and details. The contributions might be published in one issue, but most likely they will be serialised over several issues.

\section{Notes on the editors}

Adelia Peña Clavel is an English Professor and Coordinator of the Self-Access Learning CentreMediateca - at the National School of Languages, Linguistics and Translation at the National Autonomous University of Mexico in Mexico City, Mexico. She holds two master's degrees; one in Educational Technology from the Monterrey Institute of Technology and Higher Education and the other in Virtual Environments from the University of Panama and Virtual Educa. Her research interests include advising in language learning, learner autonomy, identity, and teletandem. 
Jo Mynard is a Professor in the English Department, Director of the Self-Access Learning Center, and Director of the Research Institute for Learner Autonomy Education at Kanda University of International Studies in Chiba, Japan. She holds an M.Phil in Applied Linguistics (Trinity College Dublin, Ireland) and an Ed.D. in TEFL (University of Exeter, UK). Her research interests include advising in language learning, the psychology of language learning, and learning beyond the classroom.

Honggang Liu works as a full professor of applied linguistics in the Department of English, School of Foreign Languages, Northeast Normal University (NENU), China. His research focuses on applied linguistics with more intensive attention on the areas of the psychology of language learning and teaching (motivation, learning strategies, emotions, agency, etc.), social class and foreign language learning, and language teacher education.

Tarik Uzun is an instructor, a learning advisor, and the coordinator of the Independent Learning Center (ILC) at Ankara Yildirim Beyazit University, Turkey. He teaches English and Turkish as foreign languages. He holds a Ph.D. in foreign language teaching. His research interests include pronunciation teaching, intelligibility, learner autonomy, and self-access language learning.

Hisako Yamashita is a lecturer and learning advisor at Konan Women's University in Kobe, Japan. She is the Student Involvement Coordinator and former President of the Japan Association for SelfAccess Learning (JASAL). Her research interests include affordances, reflective dialogues and learner autonomy.

\section{References}

Carson, L, \& Mynard. J. (2012). Introduction. In J. Mynard \& L. Carson (Eds.), Advising in language learning: Dialogue, tools and context (pp. 3-5). Pearson Education.

Mynard, J. (2019). Advising and self-access learning: Promoting language learner autonomy beyond the classroom. In H. Reinders, S. Ryan, \& S. Nakamura (Eds.) Innovations in language learning and teaching: The case of Japan (pp. 185-220). Palgrave Macmillan.

Mynard, J. (2020). Ethnographies of self-access language learning. Studies in Self-Access Learning Journal, 11(2), 86-92. https://doi.org/10.37237/110203

Werner, R. J. (2020). 'A puzzle that needs to be fitted together': The beginning of my autoethnographic journey of learning French through music. Studies in Self-Access Learning Journal, 11(2), 93-107. https://doi.org/10.37237/110204 